\title{
Biological technique used as alternative method in the vaccine potency assays; in-house sandwich ELISA for Rabbit haemorrhagic disease virus
}

\author{
STELIAN BARAITAREANU ${ }^{*}$, MARIUS DAN ${ }^{2}$, DOINA DANES ${ }^{1}$
}

${ }^{1}$ University of Agronomical Sciences and Veterinary Medicine of Bucharest, Splaiul Independentei 105, sector 5, 050097, Bucharest, Romania

${ }^{2}$ Institute for Control of Biological Products and Veterinary Medicines, Department of Clinical Sciences, Faculty of Veterinary Medicine, Str. Dudului 39, sector 6, 060603, Bucharest, Romania

\begin{abstract}
A biological technique wich is extensivelly used in the antigen detection and measurement is enzime linked immunosorbent assay (ELISA). In veterinary medicine, this technique is ussualy used in surveillance or control programs to establish antigenic prevalence and as a diagnostic tool for antigenic type detection (e.g., RHDV typing). In vaccinology, potency assessment (PA) of the vaccine batches is based more frequently on antibody detection using appropriate methods and less in using antigenic methods. The aim of paper is to assess the reliability of an in-house RHDV-Ag sandwich ELISA (sELISA) for PA. Batches of RHDV vaccine containing VSHI-CN-6 strain were tested with sELISA. Using the same batches, the potency tests were carried out according with European Pharmacopoeia 9.0. Healthy rabbits were vaccinated and the immune response was evaluated. The sELISA positive values (OD>300) were at the dilutions $>1 / 64$. The HI values of rabbit sera immunised with the same vaccine batches ranged between $1 / 128$ and 1/2048. The sELISA could be a reliable alternative for the evaluation of the potency test for the RHDV vaccine batches. The sELISA is faster (1-2 days) than $\mathrm{HI}$ (>42 days) and is carried in respect with the regulation concerning the use of animals for medical purposes.
\end{abstract}

Keywords ELISA, potency test, RHDV, vaccine.

To cite this article: BARAITAREANU S, DAN M, DANES D. Biological technique used as alternative method in the vaccine potency assays: in-house sandwich ELISA for Rabbit haemorrhagic disease virus. Rom Biotechnol Lett. 2020; 25(1): 1121-1127. DOI: $10.25083 / \mathrm{rbl} / 25.1 / 1121.1127$

$\square$ *Corresponding author: STELIAN BARAITAREANU, Doctor of Veterinary Medicine, PhD, Associate Professor, Department of Clinical Sciences, Faculty of Veterinary Medicine, University of Agronomical Sciences and Veterinary Medicine of Bucharest, Splaiul Independentei 105, sector 5, 050097, Bucharest, Romania, Tel/Fax: +4021- 318.04.69 / +4021- 318.04.98 E-mail: stelianbaraitareanu@fmvb.ro MARIUS DAN, Doctor of Veterinary Medicine, PhD, Institute for Control of Biological Products and Veterinary Medicines, Str. Dudului 39, sector 6, 060603, Bucharest, Romania E-mail: dan.fmarius@yahoo.com 


\section{Introduction}

One of the greatest contributions of biomedical sciences has been the vaccines development to prevent infectious diseases (TOMAR \& al, 2005 [1]). The history of vaccines began in 1796, when the pioneer of smallpox vaccine Edward Jenner (1749-1823) demonstrated the protective effect of the cowpox virus against the smallpox virus infection in humans (BAXBY, 1999 [2]). Initially, empirical vaccines (derived from killed pathogenic organism) were used, but the development of biological sciences (e.g., biochemistry, cell culture technology, immunology, molecular biology, molecular genetics) led to a new generation of vaccines, safer and immunogenic, that are based on scientific design approaches (TOMAR \& al, 2005 [1]; PLOTKIN, 2014 [3]). In the same way, the vaccine potency assays evolved from the expensive and laborious in vivo assays (e.g., immunization of dozens of animals) to the inexpensive and simple modern analytical tools (e.g., immunochemical methods) (VERCH \& al, 2018 [4]). The in vitro vaccine potency assays seem to be the best approach because they avoid the use of experimental animals and the antigen determination or activity determination by using relevant immunoassays become the most extended methods of in vitro potency assays in veterinary vaccinology (LUCKEN, 1999 [5]; HENDRIKSEN, 2009 [6]; BROWN \& STOKES, 2012 [7]; ROMBERG \& al, 2012 [8]).

Enzime linked immunosorbent assay (ELISA) has significant value in biotechnology processes. It can be used to detect both antibodies (Ab) and antigens (Ag) concentrations in various weys (e.g., direct, indirect, competitive and sandwich ELISA) and for various infectious agents (BANG \& al, 2012 [9]; TIRZIU \& al, 2014 [10]; GURAU \& al, 2015 [11]; DASCALU \& al, 2016 [12]; ENACHE \& al, 2017 [13]; BARAITAREANU \& al, 2018 [14]).

The interest in developing rabbit immunological products is part of the rabbit health management that include various reseach studies designed to improve the health and welfare of domestic rabbits. Romanian scientific studies have been covering morphophysiology (DOJANA $\&$ al, 2005 [15]; STAN, 2013 [16]; BALACEANU \& al, 2017 [17]) and pathology (DAN \& al, 2013 [18]) of domestic rabbits, including lagomorphs' calicivirus infections: rabbit haemorrhagic disease (RHD) and European brown hare syndrome (EBHS) (DAN \& al, 2015 [19]).

Rabbit haemorrhagic disease viruses (RHDV) are Lagoviruses of the Caliciviridae family, causing severe, highly contagious, fulminant and usually fatal diseases, characterized by acute necrotizing hepatitis, haemorrhages in many organs (particularly the lungs, heart and kidneys) and disseminated intravascular coagulation (ABRANTES \& al, 2012 [20]; DAN \& al, 2015 [21]). Based on phylogenetic relationships, Le Pendu \& al (2017) proposed a new nomenclature of Lagovirus genus, with a single species called Lagovirus europaeus, two genogroups (GI for RHDV - and GII for EBHSV - related viruses) and several genotypes and variants (LE PENDU \& al, 2017 [22]). Test methods available for the diagnostic of rabbit haemorrhagic disease
(RHD) are designed for the agent identification (antigen detection by sandwich ELISA, nucleic acid recognition by real-time RT-PCR, electron microscopy, hemagglutination test, immunostaining, western blotting, and rabbit inoculation) and for the detection of immune response (hemagglutination inhibition assay, indirect ELISA, competitive ELISA. Solid-phase ELISA, sandwich ELISA to detect IgM and IgG and isotype ELISAs) (OIE, 2016 [23]). In potency tests of RHDV vaccine batches, serological methods are more frequently used, while antigen detection with monoclonal antibodies is used in RHDV typing (CAPUCCI \& al, 1995 [24]). In Romania, the interest for RHDV research has been related to the history of the virus circulation and to the developing and testing of immunological products (DAN $\&$ al, 2013 [21], 2015 [25]). In this study the aim is to assess the reliability of an in-house RHDV-Ag sandwich ELISA (sELISA) in immunological products testing.

\section{Materials and Methods}

\section{Animals and serum samples}

The potency tests used 28 rabbits (New Zealand breed, 12 weeks old, free from antibodies against RHDV and from the same healthy stock) in accord with European Pharmacopoeia 9.0 (EDQM, 2017 [26]) recommendations. All animals were housed and handled in accordance with the Directive 2010/63/EU of the European Parliament and of the Council. Blood serum samples were obtained from each rabbit just before administration of the RHDV vaccine and 42 days after the inoculation of the first vaccinal dose. Each serum sample was analysed in serial dilutions, from $1 / 2$ to $1 / 4096$.

\section{RHDV vaccine, vaccinal doses and serial dilutions}

Four batches of RHDV vaccine containing VSHICN-6 strain (commercial product) were tested. In accord with the manufacturer recomandations, one vaccinal dose was used in the immunisation of rabbits included in the potency tests. Serial dilutions from $1 / 2$ to $1 / 256$ and the dilutions $1 / 3,1 / 6,1 / 12,1 / 24,1 / 48,1 / 96,1 / 192$ and 1/384 of the RHDV vaccine batches were used in the in-house sandwich ELISA (IZSLER Brescia, Italy).

\section{Batch potency test}

Each batch was tested for potency in accord with European Pharmacopoeia 9.0 by inoculating one dose of vaccine, intramuscularly, to each of 5 healthy rabbits in Day 0 and boostered in Day 21. Two rabbits were maintained as controls for each batch potency test. The level of serum antibodies of each sample was determined by hemagglutination inhibition assay (HI). The test is not valid if the sera collected from the controls and from the rabbits just before the administration of the vaccine show detectable specific antibodies (EDQM, 2017 [26]).

\section{Hemagglutination inhibition assay $(\mathrm{HI})$}

Identification of anti-RHDV specific antibodies by HI was in accord with the OIE recomandations (OIE, 2016 [23]). Briefly, HI was performed in serial dilutions of blood sera from tested animals (RHDV - vaccinated rabbits) as 
source of antibodies in titration microplates, using, as source of antigen, liver tissue extract or rabbit spleen experimentally infected with RHDV.

Hemagglutinating activity was evaluated by using human $\mathrm{O}$ group red cell suspensions in the concentration of $1 \%$ and $10 \%$. Results were validated if the negative control serum expressed a titre under $1 / 4$.

The HI titre was the last dilution of the investigated serum that completely inhibit the haemagglutination (with 4 HA units of antigen).

\section{Sandwich ELISA}

Identification and titration of RHDV-Ag in RHDV vaccine used an in-house sandwich ELISA developed by the IZSLER (Brescia, Italy). Initialy, the method was designed to identify RHDV isolates from liver and / or spleen samples and to determine whether the isolates identified had an antigenic profile similar to the reference strains, Brescia 89 classical strain and RHDV Italy 1997 strain. For our purpouse it was used only one monoclonal antibody, respectively 1H8, RHDV Brescia89, that detect the classical VSHI-CN-6 strain of the RHDV vaccine. Each sample was run in replicates and two series of dilutions (from $1 / 2$ to $1 / 256$, and from $1 / 3$ to $1 / 384$ ) were used for each sample of vaccine batch.

The microplate was read on a spectrophotometer using a $492 \mathrm{~nm}$ filter and the samples with optical density (OD) values $>300$ were considered positive.

\section{Results and Discussions}

One of the most effective ways to prevent RHD is vaccination, and achieving this goal implies the use of safe and effective vaccine, programs to deliver it to rabbit groups and strategies for disease control. The main method of the vaccine quality evaluation is potency assay that is directly or indirectly related with the product ability to produce an effective level of protection in vaccinated animals (Hendriksen, 1998 [26]). The in vivo vaccine potency assays are not all the time the best option, and the use of alternative in vitro methods with appropriate relevance to replace, reduce and revine the animal use need to be considered. This concept was proposed for the first time by William Russell and Rex Burch in their book 'The Principles of Humane Experimental Technique' (Russell \& Burch, 1959 [27]) and later, various regulatory bodies encourages the development of in vitro alternative vaccine potency assays (EDQM, 2017 [28]). In accord with the European Pharmacopoeia (Ph. Eur.) 9th Edition, in European Union countryes the potency test can be done with an alternate validated method, "the criteria for acceptance being set with reference to a batch of vaccine that has given satisfactory results in the test described under Potency" (EDQM, 2017 [28]).

\section{In vivo vaccine potency evaluation through hemag- glutination inhibition assay $(\mathrm{HI})$}

For the in vivo potency assay, four different vaccine batches were selected and the same immunization protocol followed by titration of antibodies through $\mathrm{HI}$ was performed. The HI values ranged between $1 / 128$ and 1/2048 (Tables 1-4) in all groups: values above the protective threshold (Fig. 1). The results proved the consistency of the vaccine batches quality which has been shown to be safe and efficacious in the target animal species.

Table 1. Hemagglutination inhibition assay results for the RHDV vaccine Bach \#1

\begin{tabular}{|c|c|c|c|}
\hline \multirow{2}{*}{$\begin{array}{l}\text { Rabbit } \\
\text { number code }\end{array}$} & \multirow{2}{*}{ Immunological status } & \multicolumn{2}{|l|}{ HI Assay } \\
\hline & & Titer & Interpretation \\
\hline$\# 1$ & Vaccinated & $1 / 512$ & Positiv \\
\hline$\# 2$ & Vaccinated & $1 / 512$ & Positiv \\
\hline$\# 3$ & Vaccinated & $1 / 128$ & Positiv \\
\hline \#4 & Vaccinated & $1 / 128$ & Positiv \\
\hline$\# 5$ & Vaccinated & $1 / 1024$ & Positiv \\
\hline \#6 & Unvaccinated & $1 / 4<$ & Negative \\
\hline$\# 7$ & Unvaccinated & $1 / 4<$ & Negative \\
\hline
\end{tabular}

Table 2. Hemagglutination inhibition assay results for the RHDV vaccine Bach \#2

\begin{tabular}{llll}
\hline $\begin{array}{l}\text { Rabbit } \\
\text { number code }\end{array}$ & \multirow{2}{*}{ Immunological status } & HI Assay & Interpretation \\
\hline \hline$\# 8$ & Vaccinated & Titer & Positiv \\
\hline$\# 9$ & Vaccinated & $1 / 256$ & Positiv \\
\hline$\# 10$ & Vaccinated & $1 / 256$ & Positiv \\
\hline$\# 11$ & Vaccinated & $1 / 256$ & Positiv \\
\hline$\# 12$ & Vaccinated & $1 / 256$ & Positiv \\
\hline$\# 13$ & Unvaccinated & $1 / 2048$ & Negative \\
\hline \hline 14 & Unvaccinated & $1 / 4<$ & Negative \\
\hline \hline
\end{tabular}


Table 3. Hemagglutination inhibition assay results for the RHDV vaccine Bach \#3

\begin{tabular}{lcll}
\hline $\begin{array}{l}\text { Rabbit } \\
\text { number code }\end{array}$ & \multirow{2}{*}{ Immunological status } & HI Assay & Interpretation \\
\cline { 2 - 4 }$\# \mathbf{1 5}$ & Vaccinated & Titer & Positiv \\
\hline$\# \mathbf{1 6}$ & Vaccinated & $1 / 128$ & Positiv \\
\hline$\# \mathbf{1 7}$ & Vaccinated & $1 / 128$ & Positiv \\
\hline$\# \mathbf{1 8}$ & Vaccinated & $1 / 512$ & Positiv \\
\hline$\# \mathbf{1 9}$ & Vaccinated & $1 / 512$ & Positiv \\
\hline $\mathbf{\# 2 1}$ & Unvaccinated & $1 / 512$ & Negative \\
\hline \hline
\end{tabular}

\begin{tabular}{lccc}
\hline & \multicolumn{2}{c}{ Table 4. Hemagglutination inhibition assay results for the RHDV vaccine Bach \#4 } \\
\cline { 2 - 4 } $\begin{array}{l}\text { Rabbit } \\
\text { number code }\end{array}$ & \multirow{2}{*}{ Immunological status } & Titer & \\
\hline $\mathbf{\# 2 2}$ & Vaccinated & $1 / 512$ & Interpretation \\
\hline $\mathbf{2 3}$ & Vaccinated & $1 / 512$ & Positiv \\
\hline $\mathbf{2 4}$ & Vaccinated & $1 / 512$ & Positiv \\
\hline $\mathbf{2 5}$ & Vaccinated & $1 / 512$ & Positiv \\
\hline $\mathbf{2 6}$ & Vaccinated & $1 / 1024$ & Positiv \\
\hline $\mathbf{2 7}$ & Unvaccinated & $1 / 4<$ & Positiv \\
\hline $\mathbf{2 8}$ & Unvaccinated & $1 / 4<$ & Negative \\
\hline
\end{tabular}

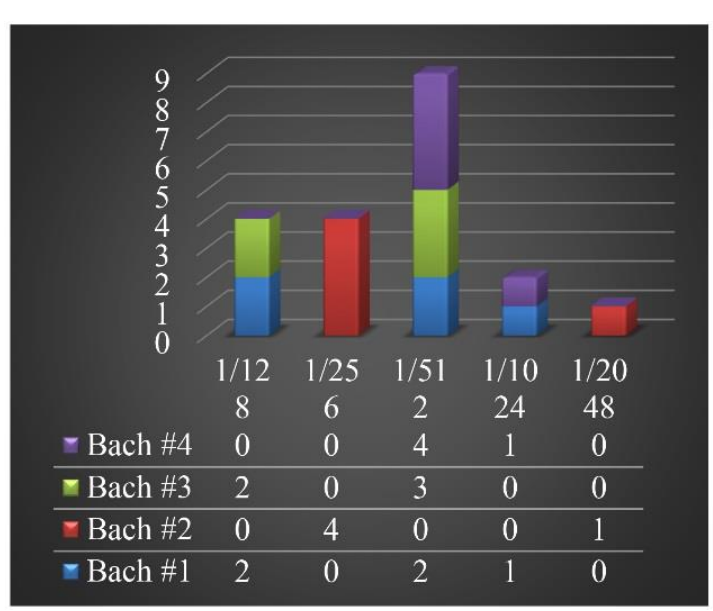

Figure 1. Hemagglutination inhibition assay titers for the RHDV vaccines.
Therefore, there can be done the testing of sELISA as an alternative methods based on the "Replacement, Reduction, and Refinement-of animal testing" principles for potency testing of RHDV vaccine containing VSHI-CN-6 strain to establish consistency in different batches can be done.

\section{In vitro vaccine potency evaluation through Sandwich ELISA}

In-vitro antigen quantification assays represent the most promising alternatives in the replacement of vaccine potency tests that use animals, but these methods are still underused (Kumar \& al, 2018 [29]).

The sELISA identified positive OD values $(>300)$ at vaccine dilutions higher than $1 / 64$ (Fig. 2). One bach vaccine provided positive results at a dilution of 1/96 (Table 5).

Table 5. Titer values of positive results of Sandwich ELISA

\begin{tabular}{cccc}
\hline \multirow{2}{*}{ Test number } & \multicolumn{3}{l}{ Sandwich ELISA-RHDV with 1H8 HRP } \\
\cline { 2 - 4 } & Value of serial dilutions & OD & \\
\hline \hline $\mathbf{1 .}$ & $1 / 96$ & $350 / 80$ & Interpretation \\
\hline $\mathbf{2 .}$ & $1 / 96$ & $330 / 77$ & Positiv \\
\hline \hline $\mathbf{3 .}$ & $1 / 64$ & $470 / 80$ & Positiv \\
\hline $\mathbf{4 .}$ & $1 / 64$ & $368 / 58$ & Positiv \\
\hline \hline $\mathbf{5 .}$ & $1 / 64$ & $463 / 83$ & Positiv \\
\hline $\mathbf{6 .}$ & $1 / 64$ & $445 / 78$ & Positiv \\
\hline \hline $\mathbf{7 .}$ & $1 / 64$ & $358 / 57$ & Positiv \\
\hline $\mathbf{8 .}$ & $1 / 64$ & $370 / 67$ & Positiv \\
\hline
\end{tabular}




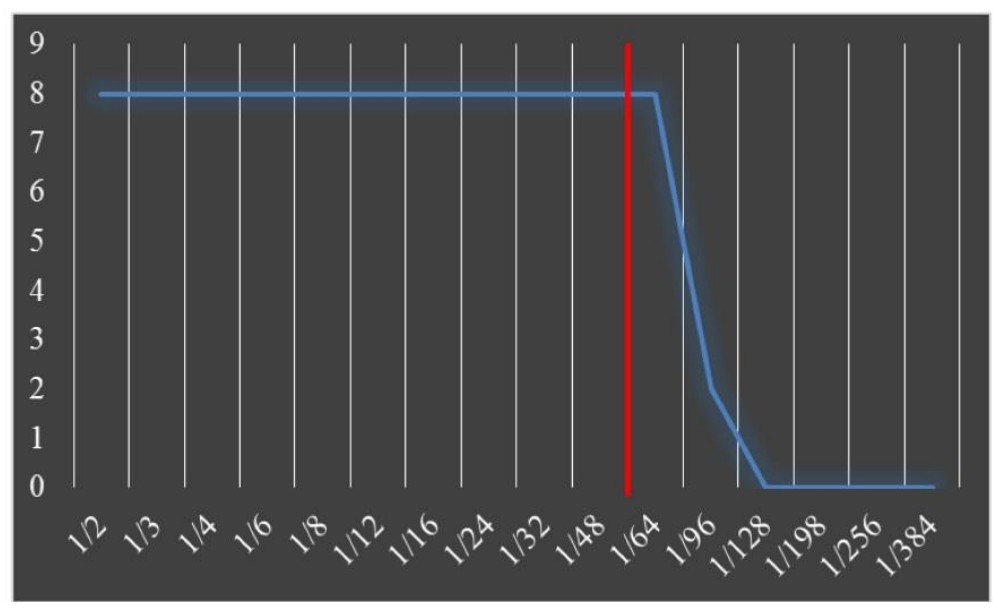

Figure 2. Sandwich ELISA titers of four RHDV vaccine batches. Each batch was run in replicates and two series of dilutions (from $1 / 2$ to $1 / 256$, and from $1 / 3$ to 1/384). Red line: dilution at which all the batches provided positive values.

\section{In vivo potency assay vs in vitro potency assay}

In our study, both metods provided positive results for all vaccine baches, and these results allow to relate the correspondence between sELISA (antigen quantifying) values at a dilution $>1 / 64$ and $\mathrm{HI}$ (antibody quantifying) values at a titer $>1 / 512$, and provide an option for the same purpose.

Corroborating the results obtained by the detection of vaccine antigen using SELISA with the immune response expressed by haemagglutinating antibodies, it was observed that a vaccine dose diluted $1 / 64$ provided a positive OD value and, at the same time, the same vaccine dose, ensured the antibody protective level. Starting from this observation, the proposed sELISA tool could be used as a method of evaluating the potency of the vaccine: the value of OD (> 300) for a dilution of vaccine antigen of 1/64 could be the criterion for admissibility of the vaccine batch. However, the results shoud be interepreted with precaution because some RHDV isolates are thermosensitive, exhibiting variable hemagglutinating characteristics, and some ELISA positive samples can give negative results to the haemagglutination test (CAPUCCI \& al, 1996 [30]). However, atleast two limitation of the antigen quantification test could be considered: (1) antigen quantity in beach vaccine do not necessarily reflect biological activity, and (2) inactivated vaccines may include an adjuvant that interfere with assay (McFarland \& al, 1996 [31]). Therefore, the adjuvant removal from the product before testing and evaluation of the antigen integrity before adjuvant removal need to be considerated (McFarland \& al, 1996 [31]; Hendriksen, 2009 [32]).

\section{Conclusions}

The sELISA seem to be a reliable alternative for the evaluation of the potency test for the RHDV vaccines. The sELISA is faster (1-2 days) than HI (>42 days) and is carried in respect with the regulation concerning the use of animals for medical purposes.

\section{Conflict of interest disclosure}

There are no known conflicts of interest in the publication of this article. The manuscript was read and approved by all authors.

\section{Compliance with ethical standards}

Any aspect of the work covered in this manuscript has been conducted with the ethical approval of all relevant bodies and that such approvals are acknowledged within the manuscript.

\section{Acknowledgments}

This research did not receive any specific grant from funding agencies in the public, commercial, or not-forprofit sectors. The original working hypothesis and part of the research were done by Marius DAN at Istituto Zooprofilattico Sperimentale della Lombardia e dell'Emilia Romagna "B. Umbertini". Special thanks to Dr. Antonio Lavazza, Dr. Steluta Rosu, Daniella Lavazza, Cristina Palotta, Giovanni Bozzoni, Giuseppe Bertocchi. All authors have contributed equally.

\section{References}

1. D. TOMAR, V.CHATTREE, V. TRIPATHI, A.A. KHAN, A.R. BAKSHI, D.N. RAO, New dimensions in vaccinology: A new insight. Indian Journal of Clinical Biochemistry. 20(1), 213-230 (2005).

2. D. BAXBY, Edward Jenner's inquiry; a bicentenary analysis. Vaccine, 17(4), 301-307 (1999). 
3. S. PLOTKIN, History of vaccination. Proceedings of the National Academy of Sciences of the United States of America, 111(34), 12283-12287 (2014).

4. T. VERCH, J.J. TRAUSCH, M. SHANK-RETZLAFF, Principles of vaccine potency assays. Bioanalysis, 10(3), 163-180 (2018).

5. R.N. LUCKEN, Alternatives to in vivo potency and protection tests for veterinary vaccines. Developments in biological standardization, 101, 67-72 (1999).

6. C.F. HENDRIKSEN, Replacement, reduction and refinement alternatives to animal use in vaccine potency measurement. Expert Review of Vaccines, 8(3), 313-322 (2009).

7. K. BROWN, W. STOKES, In vitro vaccine potency testing: a proposal for reducing animal use for requalification testing. Developments in biologicals (Basel). 134, 75-81 (2012).

8. J. ROMBERG, S. LANG, E. BALKS, E. KAMPHUIS, K. DUCHOW, D. LOOS, H. RAU, A. MOTITSCHKE, C. JUNGBACK. Potency testing of veterinary vaccines: the way from in vivo to in vitro. Biologicals, 40(1), 100-106 (2012).

9. J. BANG, S. SHUKLA, Y.H. KIM, M. KIM, Development of indirect competitive ELISA for the detection of Salmonella typhimurium. Romanian Biotechnological Letters, 17(2), 7194-7204 (2012).

10. E. TIRZIU, C. CUMPANANSOIU, I. NICHITA, G.D. REMAN, C. SONEA, M. SERES, Performance assessment of three tests applied in enzootic bovine leukosis diagnosis. Romanian Biotechnological Letters, 19(5), 9666-9677 (2014).

11. M.R. GURAU, S. BARAITAREANU, D. Danes, Serological survey of caprine arthritis encephalitis virus infection in a southeastern Romanian farm. Scientific Works. Series C Veterinary Medicine, 61(2), 169-171 (2015).

12. M.A. DASCALU, F. DARABAN, M. DAN, D. DANES, S. BARAITAREANU, O.I. TANASE, E. VELESCU, Detection of antibodies against rabies virus in foxes serum after oral vaccination campaign in Buzau and Galati Counties. Bulletin of University of Agricultural Sciences and Veterinary Medicine ClujNapoca. Veterinary Medicine, 73(1), 49-56 (2016).

13. D.A. ENACHE, S. BARAITAREANU, M. DAN, M.R. GURAU, F. OTELEA, A. DOBRE, D. DANES, Preliminary results of $\mathrm{MVV}$ and CAEV seroprevalence in Romanian sheep and goats. Scientific Works. Series C Veterinary Medicine, 63(1), 95-100 (2017).

14. S. BĂRĂITĂREANU, Y.A. OZDEMIR, M. DAN, Serological detection of anti-Coxiella burnetii antibodies in Romanian small ruminants. Revista Română de Medicină Veterinară, 28(3), 18-24 (2018).
15. N. DOJANA, A. POP, C. PAPUC, Effects of exogenously added short-chain fatty acids on pancreatic exocrine secretion in domestic rabbit. Proceedings of the $8^{\text {th }}$ World Rabbit Congress, September 7-10, 2004, Pueblo, Mexico, 1072-1078 (2005).

16. F. STAN, Comparative study of the stomach morphology in rabbit and chinchilla. AgroLife Scientific Journal, 2(2), 73-78 (2013).

17. R. BALACEANU, L. STOICA, M. GHITA, L. OGNEAN, I. NEGOITA, N. DOJANA, The effect of different fibre and starch dietary levels on haematology of post-weaning rabbits. Agrolife Scientific Journal, 6(2), 22-26 (2017).

18. M. DAN, S. BĂRĂITĂREANU, D. DANEȘ, Myxomatosis, diagnostic prevention and control. Revista Română de Medicină Veterinară, 23(4), 11-22 (2013).

19. M. DAN, S. BĂRĂITĂREANU, D. DANEȘ, Risk factors for the emergence/re-emergence of lagomorphs' calicivirus infections. Scientific Works. Series C Veterinary Medicine, 61 (2), 172-175 (2015).

20. J. ABRANTES, W. VAN DER LOO, J. LE PENDU, P.J. ESTEVES, Rabbit haemorrhagic disease (RHD) and rabbit haemorrhagic disease virus (RHDV): a review. Veterinary Research, 43, 12-19 (2012).

21. M. DAN, S. BARAITAREANU, A.F. VLADIMIRESCU, D. DANES, Rabbit haemorrhagic disease virus strains isolated in Romania. Journal of Biotechnology, 208(Supplement), S89-S89 (2015).

22. J. LE PENDU, J. ABRANTES, S. BERTAGNOLI, J.S. GUITTON, G. LE GALL-RECULÉ, A.M. LOPES, S. MARCHANDEAU, F. ALDA, T. ALMEIDA, A.P. CÉLIO, J. BÁRCENA, G. BURMAKINA, E. BLANCO, C. CALVETE, P. CAVADINI, B. COOKE, K. DALTON, M. DELIBES, W. DEPTULA, J.S. EDEN, F. WANG, C.C. FERREIRA, P. FERREIRA, P. FORONDA, D. GONÇALVES, D. GAVIER-WIDÉN, R. HALL, B. HUKOWSKASZEMATOWICZ, P. KERR, J. KOVALISKI, A. LAVAZZA, J. MAHAR, A. MALOGOLOVKIN, R.M. MARQUES, S. MARQUES, A. MARTINALONSO, P. MONTERROSO, S. MORENO, G. MUTZE, A. NEIMANIS, P. NIEDZWIEDZKARYSTWEJ, D. PEACOCK, F. PARRA, M. ROCCHI, C. ROUCO, N. RUVOËN-CLOUET, E. SILVA, D. SILVÉRIO, T. STRIVE, G. THOMPSON, B. TOKARZ-DEPTULA, P. ESTEVES, Proposal for a unified classification system and nomenclature of lagoviruses. Journal of General Virology, 98, 16581666 (2017).

23. OIE (WORLD ORGANISATION FOR ANIMAL HEALTH), Chapter 2.6.2. Rabbit haemorrhagic disease, OIE Manual of Diagnostic Tests and Vaccines for 
Terrestrial Animals, URL http://www.oie.int/fileadmin/ Home/eng/Health_standards/tahm/2.06.02_RHD.pdf Accessed 01.09.18. (2016).

24. L. CAPUCCI, G. FRIGOLI, L. RONSHOLD, A. LAVAZZA, E. BROCCHI, C. ROSSI, Antigenicity of the rabbit hemorrhagic disease virus studied by its reactivity with monoclonal antibodies. Virus. Res., 37, 221-238 (1995).

25. M. DAN, S. BARAITAREANU, D. DANES, Comparative Study of ELISA and AGID for the Detection of Antibodies Against Rabbit Haemorrhagic Disease Virus. Bulletin UASVM, Veterinary Medicine, 70(2), 333-334 (2013).

26. C. HENDRIKSEN, Validation of Alternative Methods for the Potency Testing of Vaccines. ATLA, 26, 747-761 (1998).

27. W.M.S. RUSSELL, R.L. BURCH. Principles of Humane Experimental Technique. Methuen, London, UK (1959).

28. EDQM, Rabbit haemorrhagic disease vaccine (inactivated). In Ph. Eur. 9.0, Monograph 01/2017:2325 (pp. 1092-1093). Strasbourg: Council of Europe (2017).
29. S. KUMAR, M.P. SINGH, V.K. BHARTI, R.P. PANDEY, Quality control of vaccines-A journey from classical approach to 3Rs. Microbiology: Current Research, 2(3), 45-61 (2018).

30. L. CAPUCCI, D. CHASEY, A. LAVAZZA, D. WESTCOTT, Preliminary characterization of a non-haemagglutinating strain of rabbit haemorrhagic disease virus from the United Kingdom. Zentralbl Veterinarmed B, 43(4), 245-250 (1996).

31. R. MCFARLAND, D. VERTHELYI, W. CASEY, J. ARCINIEGA, R. ISBRUCKER, M. SCHMITT, T. FINNA, J. DESCAMPS, Y. HORIUCHI, D. SESARDIC, P. STICKINGSG, N.W. JOHNSON, E. LIPSCOMB, D. ALLEN, Non-animal replacement methods for human vaccine potency testing: state of the science and future directions. Procedia in Vaccinology, 5, 16-32 (2011).

32. C.F.M. HENDRIKSEN, Replacement, reduction and refinement alternatives to animal use in vaccine potency measurement. Expert Review of Vaccines, 8, 313-322 (2009). 